NASA Technical Memorandum 89915

AIAA-87-9080

\title{
A Prediction Model of the Depth-of-Discharge Effect on the Cycle Life of a Storage Cell
}

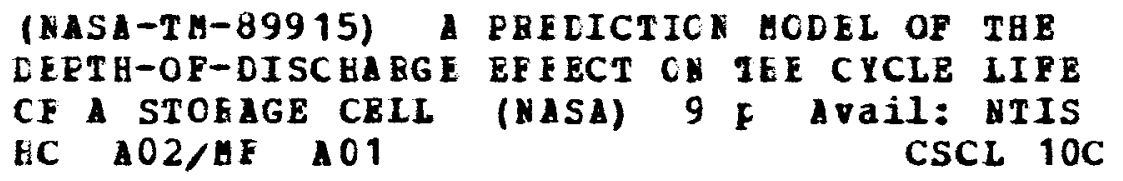

Uaclas H1/44 $00742 \vdots 1$

Lawrence H. Thaller

Lewis Research Center

Cleveland, Ohio

and

Hong S. Lim

Hughes Research Laboratories

Malibu, California

Prepared for the

22nd Intersociety Energy Conversion Engineering Conference

cosponsored by the AIAA, ANS, ASME, SAE, IEEE, ACS, and AIChE Philadelphia, Pennsylvania, August 10-14, 1987

\section{N/Sก}


Lawrence $\mathrm{H}$. Thaller

National Aeronautics and Space Administration

Lewis Research Center, Cleveland, Ohio

\author{
Hong S. Lim \\ Hughes Research Laboratories \\ Malibu, California
}

\begin{abstract}
Cycle life requirements are very high for batteries used in aerospace applications in low earth orbit. The data base required to establish confidence in a particular cell design is thus both exten. sive and expensive. Reliable accelerated cycle life testing and performance decay modeling represent attractive alternatives to real-time tests of cycle life. In light of certain long-term cycle life test results, this paper examines a very simple performance decay model developed earlier. Application of that model to available data demonstrates a rigid relationship between a battery's expected cycle life and the depth of discharge of cycling. Further, modeling analysis of the data suggests that a significantly improved cycle life can be obtained with advanced components, materials, and designs; and that cycle life can be reliably predicted from the results of accelerated testing.
\end{abstract}

\section{Introduction}

For many advanced aerospace and electric vehicle applications, where mission ife requirements cannot be compromised, high energy density of storage cells is critical. Since a battery's energy density is directly proportional to the depth of discharge (DOD) of cycling, and battery cycle life decreases rapidly as DOD is increased, it is important to quantify the relationship between cycle life and DOD. Knowledge of that relationship would permit one to predict the cycle life of batteries cycled at shallow DODs from data on accelerated cycling at deeper DODs. Shallow DODs are often required to support a long mission life. .

Several prediction models relating cycle life to DOD have been reported. 1-6 All are briefly discussed in this paper, and one is shown to be consistent with available cycle I ife data on cells that failed because of a gradual wearout mode, as opposed to catastrophic failure mechanisms. We are most interested in gradual decreases in capacity because they are by nature predictable and undoubtedly related to DOD; sudden failures, on the other hand, cannot be predicted and therefore cannot be modeled.

\section{Prediction Models}

Several equations have been proposed for predicting battery cycle 1 ife ${ }^{1-4}$ as a function of DOD as well as other parameters such as temperature, recharge ratio, charge rate, and discharge rate. The most popular one is

$$
\ln \mathrm{L}=\mathrm{A}-\alpha \mathrm{D}^{\prime}
$$

which can be transformed into

$$
L=L_{\phi} \mathrm{e}^{\alpha\left(1-0^{\prime}\right)}
$$

where $L$ is cycle life, $D^{\prime}\left(0 \leq D^{\prime} \leq 1\right)$ is the value of DOD, and $\alpha, A$, and $L_{\phi}$ are constants. The values of $A$ and $L_{\phi}$ can be affected by temperature and recharge ratio. ${ }^{2,3}$ A model (not shown here) similar to equation (1) but with an additional term for charge and discharge rate effects ${ }^{3}$ was suggested for application to data from the cycle life testing of a series of $\mathrm{Ni} / \mathrm{Cd}$ cells.

The following equation for analysis of $\mathrm{Ni} / \mathrm{Cd}$ cell data was also proposed:

$$
L=B \frac{1-D^{\prime}}{D^{\prime}}
$$

where $B$ is a constant and $D^{\prime}$ is depth of discharge as a fraction of actual capacity. This model assumes that the initial measured excess capacity (1 - D') over the cycled value ( $D^{\prime}$ ) is decreased at a rate of $D^{\prime} / B$ per cycle. Thus, the cell will fail to cycle when the capacity is reduced by $1-D^{\prime}$.

A similar model, including a new term (F) to represent excess capacity over the rated value, was suggested recently for cycle life iimited by gradual wearout: ${ }^{5}, 6$

$$
L=\frac{1+F-D}{R D}
$$

where $F$ is the excess capacity over the rated value (in units of the rated capacity), D is depth of discharge as a fraction of rated capacity, and $R$ is a constant

$$
\text { Equation (4) is essentially the same }
$$

; equation (3) in physical implications. 
However, equation (4) has the advantage of requiring only the rated, rather than the actual, value of capacity to fit data. The unequivocal value of actual capacity is not usually known, whereas the rated value is always available. This paper shows that equation (4) is consistent with existing cycle life data on storage cells that failed as a result of gradual wearout, but not catastrophic events such as shorts and other mechanical problems.

\section{Physical Implications of Proposed Model}

The proposed model, equation (4), for predicting the effect of DOD on cycle life assumes that the initial normalized excess available capacity $(1+F=D)$ over the normalized capacity being cycled (D) is decreased by a fractional amount RD per cycle. The term $R$ may be viewed as a constant associated with the rate of capacity loss. It is expressed in units of reciprocal cycles. The term $F$ is the fractional excess capacity over the nominal capacity and thus should not be affected by cycling conditions. (For further details, consult Refs. 5 and 6.)

However, $R$ will be influenced by parameters such as temperature, cycling regime, electrolyte composition (e.g., $\mathrm{KOH}$ concentration), impurities or additives in the electrolyte, amount of electrolyte in a starved cell, and chemical reactions (e.g., corrosion reactions, separator degradation). When a chemical reaction rate constitutes a substantial portion of $R$, equation (4) will be applicable only for a continuous cycle $l$ ife test, because any long interruption would allow chemical degradation without cycling.

When the natural log of cycle life L is plotted against depth of discharge D, equation (4) will yield a nonlinear sigmoid-type curve. ${ }^{5}$ However, the midportion (D>0.2;1+F-D>0.2) of the curve is roughly linear with a tangential slope, s:

$$
s=\frac{d(\ln L)}{d D}=\frac{-(1+F)}{D(1+F-D)}
$$

For example, the slope at $D=0.5$ is -4.0 when $F=0,-3.43$ when $F=0.2$, and -3.0 when $F=0.5$. The value of the slope for failure due to gradual wearout should be between -4.0 and -3.0 because $F$ should be greater than $O$ but is not likely to exceed 0.5 in an actual cell. A typical value of $\mathrm{F}$ for an aerospace $\mathrm{Ni} / \mathrm{Cd}$ cell is about 0.2 . The slope at $\mathrm{D}=0.5$ should be numerically similar to $\alpha$ of equations (1) and (2), since both $s$ and $\alpha$ are the slopes of plots of $\ell_{n} L$ as a function of DOD.

\section{Test of Model against Cycle Life Test Data on $\mathrm{Ni} / \mathrm{C} \overline{\mathrm{C}} \mathrm{Cl} 1 \mathrm{~s}$}

The proposed model, equation (4), was tested against data from two separate analyses of $\mathrm{Ni} / \mathrm{Cd}$ cell cycle life. One cycle life testing program, conducted by the Naval Weapons Support Center, evaluated parametric effects on the cycle life of a large group of $\mathrm{Ni} / \mathrm{Cd}$ cells containing nylon separators. 7,8 The other, conducted by Hughes Research Laboratories (HRL) tested $\mathrm{Ni} / \mathrm{Cd}$ boiler plate cells with polymer-reinforced $\mathrm{z}$ i rconia separators. ${ }^{9}, 16$

Figure 1 compares cycle 1 ife data from Ref. 7, Fig. VI-4, with a linear regression on those data points and a nonlinear cycle life prediction curve calculated using equation (4). The best curve fit was obtained with $F=0.2$ and $R=3.5 \mathrm{x}$ $10^{-4}$. Both the prediction curve and the linear regression line closely match the experimental data.

Figure 2 compares similar data at various temperatures, from Fig. VI-6 of Ref. 7 , with prediction curves having $\mathrm{F}=$ 0.2 and various values of $R$. Again, all curves in the figure fit fairly well to the corresponding data points; though the linear regression lines are not shown in Fig. 2, they also closely approximate the relevant data points.

The close fit of predicted to actual values when excess capacity $F$ is held constant, as in Figs. 1 and 2 , is consistent with the physical implication of the model that $F$ should not be affected by cycling conditions. Since all test cells were from a single manufacturing series, their $F$ value should be independent of test conditions. In both Fig. 1 and Fig. 2, the tangential slope [s of equation (5)] of all curves at $D=0.5$ was -3.43 . That value agrees with the reported value 2,3 of -3.8 for $\alpha$ of equation (1) for the same test data. (The value of $\alpha$ is expected to be slightly greater than that of $\mathrm{s}$.) This agreement indicates that both equations (1) and (4) fit the test data points within an experimental error.

The second set of cycle Iife data was derived from tests of $\mathrm{Ni} / \mathrm{Cd}$ boiler plate cells with polymer-reinforced zirconia separators, which are chemically stable in $\mathrm{KOH}$ electrolyte. Such cells differ from those with nylon separators 11 in that they do not suffer from separator degradation a primary cause of cell failure. There fore, for the improved cells, the value of $\mathrm{R}$ in equation (4) should be considerably less than that for the cells employing nylon separators. 


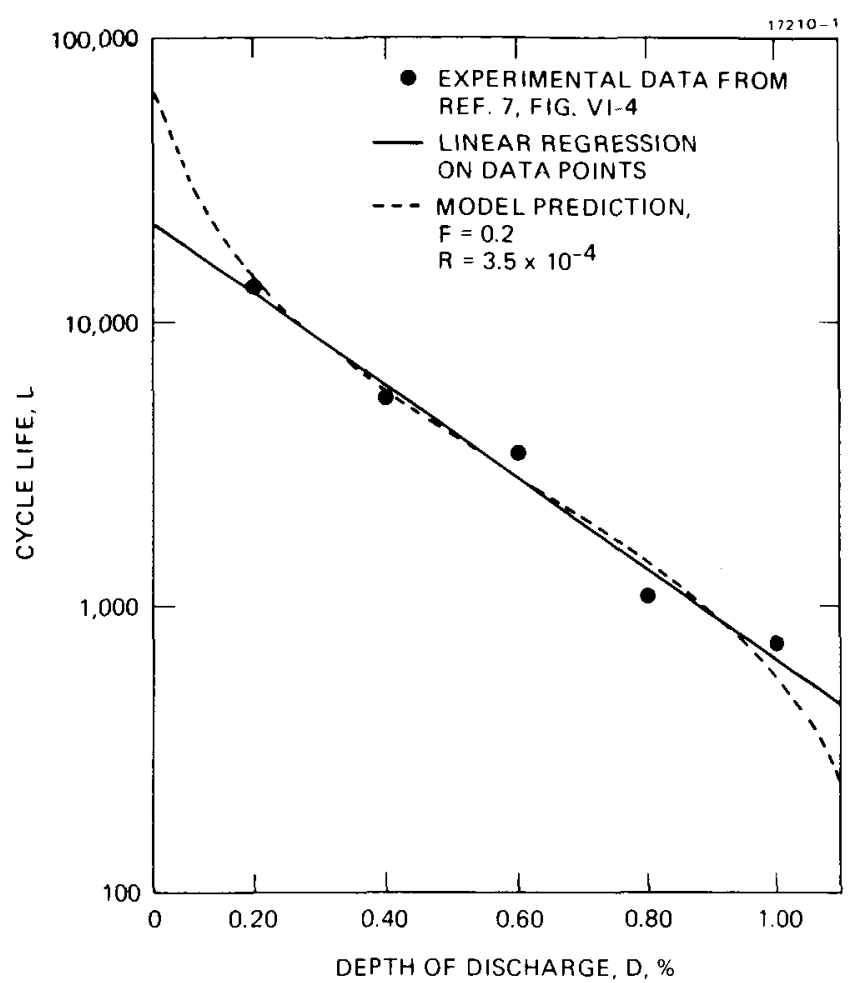

Fig. 1 Cycle life versus DOD of $\mathrm{Ni} / \mathrm{Cd}$ cells containing nylon separators: experimental values taken at $40^{\circ} \mathrm{C}$.

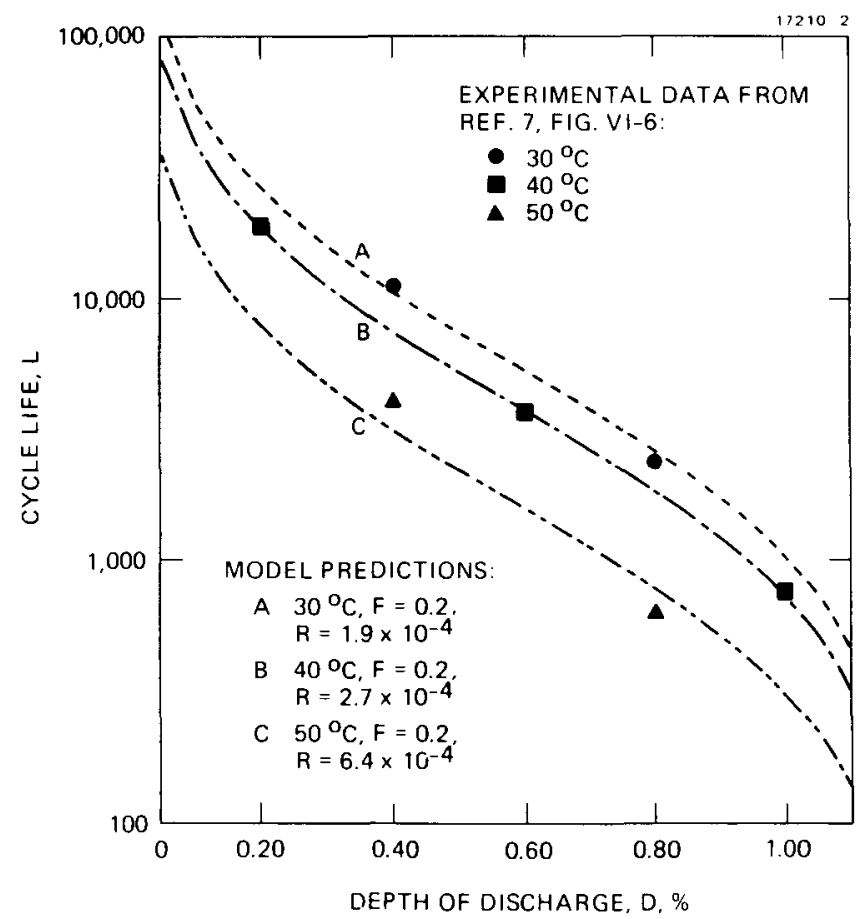

Fig. 2 Cycle life versus DOD of $\mathrm{Ni} / \mathrm{Cd}$ cells containing nylon separators: experimental values taken at $30^{\circ} \mathrm{C}$, $40^{\circ} \mathrm{C}$, and $50^{\circ} \mathrm{C}$.
The cycle life testing of the improved cells using zirconia separators was carried out in two different series. One involved type A cells containing chemically deposited nickel and cadmium elec trodes. The type A cells were tested in a cycling regime consisting of a $16 \mathrm{~min}$ discharge at a $1.5 \mathrm{C}$ rate followed by a 24 min recharge at the same rate.

The other test series involved type $B$ cells, in which the nickel electrodes were deposited electrochemically, though the cadmium electrodes were of the same lot as those in the type A cells and thus were deposited chemically. The two different types of nickel electrodes had similar values of measured capacity as well as the same rated capacity. The type B cells were tested in a cycling regime consisting of a $30 \mathrm{~min}$ discharge, either at a $1.2 \mathrm{C}$ rate to $60 \%$ DOD or at a $1.6 \mathrm{C}$ rate to $80 \%$ DOD; followed by a $40 \mathrm{~min}$ recharge at the same rates, respectively, and a $2 \mathrm{~min}$ trickle charge at $\mathrm{C} / 20$ to $\mathrm{C} / 15$ rates. Cycle life values were taken when the endof-discharge voltage reached $0.5 \mathrm{~V}$.

The following table summarizes the test data on the zirconia-separator cells, excluding those that failed because of a short formation. The data points for the two different types of cells (A and B) were not strictly comparable in either their design or the details of their cycling regime. Nevertheless, we decided to test the model using both sets of data because we believed that the difference between them would prove to be minor. However, the data points were not numerous enough to permit even a three-point comparison with prediction plots of the cycle iffe as a function of the DOD at a given temperature. Therefore, the two missing data points were estimated using an extrapolation method, described below.

Figure 3 plots the logarithmic values of cycle life at various depths of discharge and temperatures against $1 / T$. A three-point plot of experimental data on 40\% DOD (curve A) yielded a straight line with a slope corresponding to an activation energy of $11 \mathrm{kcal} / \mathrm{mole}$. We assumed the same activation energy value for $60 \%$ and 80\% DOD. Extrapolating from that value, we obtained curves $\mathrm{B}$ and $\mathrm{C}$ for $60 \%$ and $80 \%$ DOD, respectively. From curves B and $C$, cycle lives of 20,500 at $60 \%$ DOD and $25^{\circ} \mathrm{C}$ and 4,000 at $80 \%$ DOD and $40^{\circ} \mathrm{C}$, respectively, could be projected so as to produce enough estimated data points to permit a three-point comparison with prediction curves representing the effect of DOD on cycle life.

Figure 4 plots both the actual (from the table, above) and the extrapolated (from Fig. 3) data points against DOD and compares them with curves predicted using equation (4). The best fitting value of $F$ was 0.19 , indicating that the zirconiaseparator cells had an excess capacity of 
Table. Cycle life of $\mathrm{Ni} / \mathrm{Cd}$ cells with polymer-

reinforced zirconia separators at various

depths of discharge and temperatures

\begin{tabular}{|c|c|c|c|c|}
\hline $\begin{array}{c}\text { Cell } \\
\text { Type }\end{array}$ & $\begin{array}{c}\text { Number } \\
\text { of Cells }\end{array}$ & $\begin{array}{c}\text { Depth of } \\
\text { Discharge } \\
(\%)\end{array}$ & $\begin{array}{c}\text { Temperature } \\
\left({ }^{\circ} \mathrm{C}\right)\end{array}$ & $\begin{array}{c}\text { Average Cycle } \\
\text { Life }\end{array}$ \\
\hline A & 2 & 40 & 25 & 43,100 \\
A & 2 & 40 & 40 & 15,200 \\
A & 3 & 40 & 50 & 10,300 \\
B & 1 & 60 & 40 & 8,300 \\
B & 1 & 80 & 25 & 9,500 \\
\hline
\end{tabular}

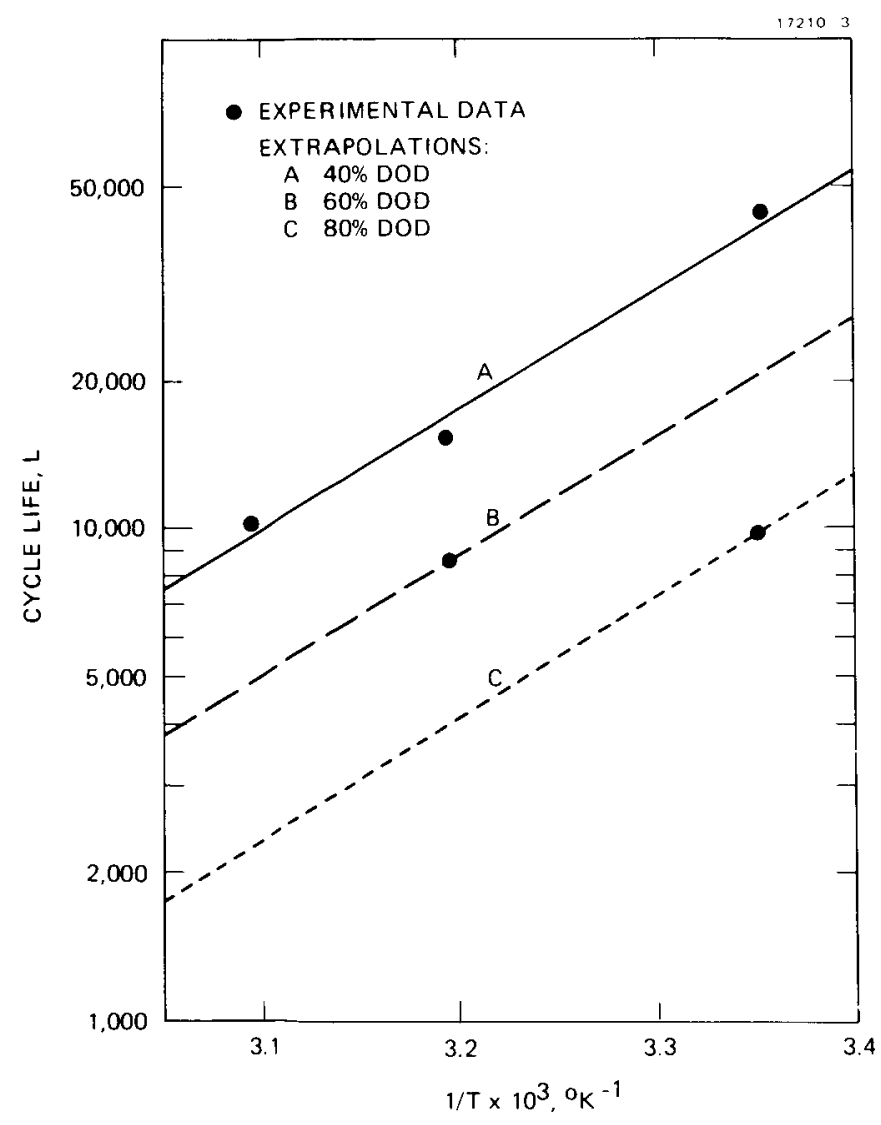

Fig. 3 Cycle life versus $1 / \mathrm{T}$ of improved $\mathrm{Ni} / \mathrm{Cd}$ cells containing zirconia separators.

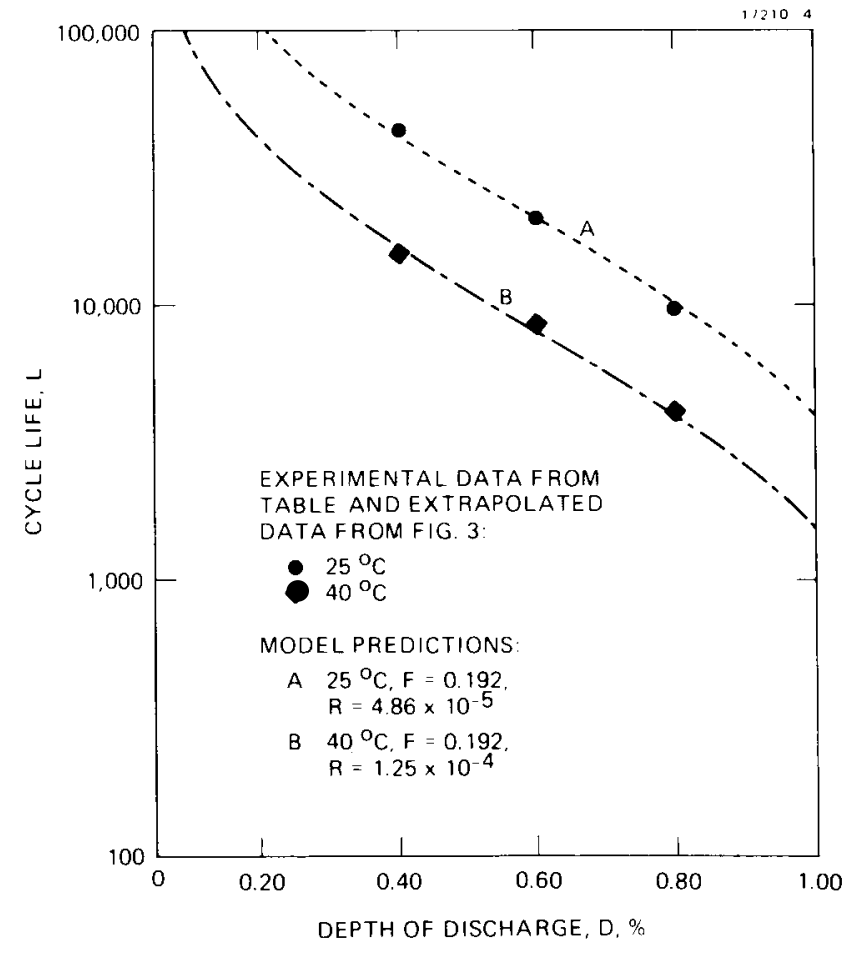

Fig. 4 Cycle life versus DOD of improved $\mathrm{Ni} / \mathrm{Cd}$ cells containing zirconia separators. 
$19 \%$ over the rated value. The best fitting values of $R$ were $4.86 \times 10^{-5}$ at $25^{\circ} \mathrm{C}$ and $1.25 \times 10^{-4}$ at $40^{\circ} \mathrm{C}$, for curves $A$ and $B$, respectively.

The prediction curves with a single $F$ value of reasonable magnitude fit remarkably well to the experimental values, despite the inhomogereity of data points discussed above. The value of $R$ ( $1.25 \mathrm{x}$ $10^{-4}$ ) at $40^{\circ} \mathrm{C}$ is less than half that of cells using nylon separators (2.7 to $3.5 \mathrm{x}$ $10^{-4}$ ) at the same temperature. Those relative magnitudes of $R$ values are also consistent with the observation that the zirconia-separator cells had much longer cycle lives than those containing nylon separators. ${ }^{16}$ Thus, the proposed model, equation (4), appears to represent the experimental data quite well.

\section{Test of Model against Cycle Life Test Data on $\mathrm{Li} / \mathrm{MoS}_{2}$ Cells}

The proposed model, equation (4), was also applied to cycle life test data on $\mathrm{Li} / \mathrm{MoS}_{2}$ cells that are reported to have failed gradually. ${ }^{12}$ Figure 5 compares cycle life data from Ref. 12 , Fig. 4, with a linear regression on those data points and a nonlinear cycle life prediction curve calculated using equation (4). The best curve fit was obtained with $F=0.20$ and $\mathrm{R}=1.14 \times 10^{-3}$. In this case, the prediction curve matches the experimental data more closely than does the linear regression line, indicating that equation (4) describes the effect of DOD better than equation ( 1 ).

\section{Discussion}

The proposed model, equation (4), for predicting the effect of DOD on the cycle ife of a storage cell seems to closely approximate available cycle life data on $\mathrm{Ni} / \mathrm{Cd}$ and $\mathrm{Li} / \mathrm{MoS}_{2}$ cells that appeared to have failed owing to gradual wearout, though the data points are too few to be statistically significant. The values of $F(0.19$ to 0.20$)$ used in our calculations produced curves that fit the corresponding data quite we1l, consistent with the physical implication of the model that $F$ should not be affected by cycling conditions.

The other model, equation (1), also fit the same data, as reported by earlier investigators. ${ }^{2}, 3$ Dverall, however, equation (4) appears to fit better than equation (1), especially for the data on $\mathrm{Li} / \mathrm{MOS}_{2}$ cells at high DOD, as shown in Fig. 5. Though equation (4) is not perfect, and additional data are needed to conclusively test the validity and relative merits of these two prediction models, equation (4) seems to be the more straightforward.

We did not test the proposed model against cycle life data on other batteries

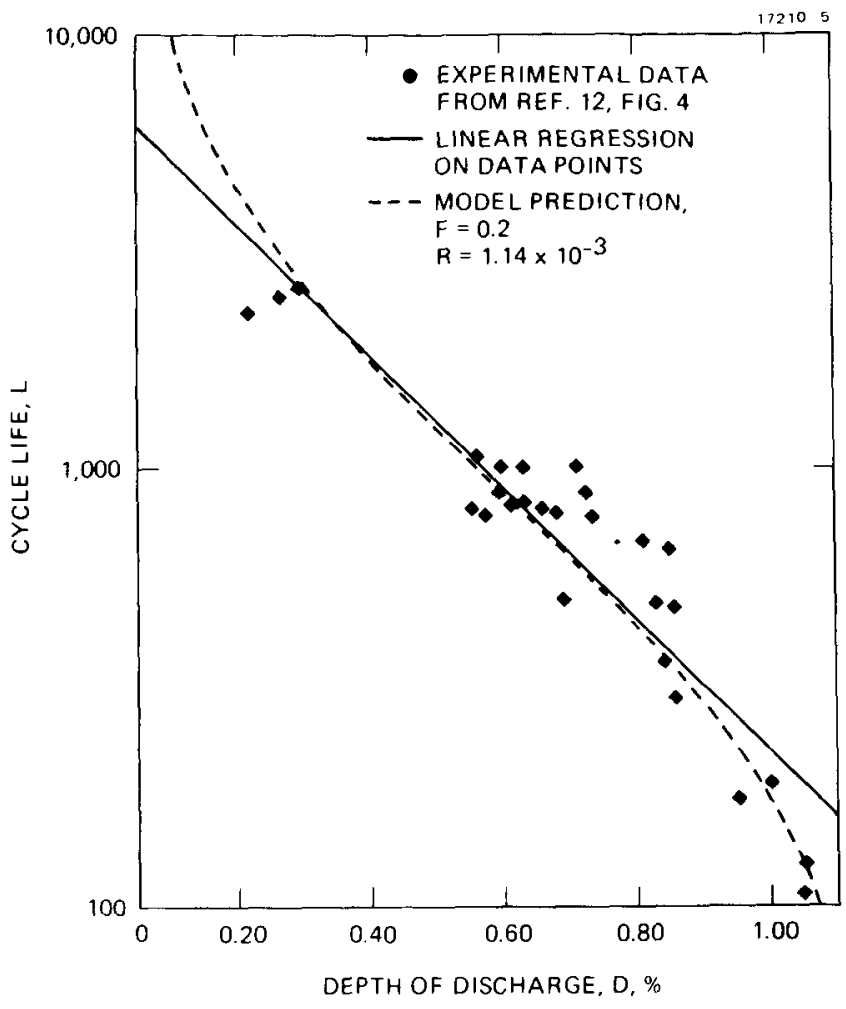

Fig. 5 Cycle life versus DOD of $\mathrm{Li} / \mathrm{MoS}_{2}$ cells.

such as nickel-zinc and lead-acid because we were not convinced that they fail gradually. Most reported values of $\alpha$ for those batteries fall outside the range predicted by equation (4). They might represent catastrophic failure of the batteries.

The proposed model is based on the assumption that cell capacity is reduced at a constant rate per cycle. Unfortunately, existing data on cell capacity as a function of cycle life for $\mathrm{Ni} / \mathrm{Cd}$ and $\mathrm{Li} / \mathrm{MoS}_{2}$ cells are unsuitable for testing that assumption. Though data are available on capacity as a function of cycle number for $\mathrm{Ni} / \mathrm{H}_{2}$ cells, 13,14 their capacity was not measured in the same regime as that of cycling. The cycling regime of that test was a 45-min low earth orbit (LEO), whereas capacity was measured using the charge and discharge rates of a 90-min LED regime. The resulting capacity data did not show a constant rate of capacity reduction. Some cells showed a roughly linear decrease ${ }^{13}$ and others showed a clearly nonlinear decrease. ${ }^{14}$ In another experiment, conducted by HRL, a sintered nickel electrode was cycled at $100 \%$ depth of discharge in a flooded $26 \% \mathrm{KOH}$ electrolyte. The change in its capacity was roughly linear with the number of cycles, as shown in Fig. 6, supporting the assumption of the proposed model.

Equation (4) implies that the dependence of cycle 1 ife on DOD is not affected 


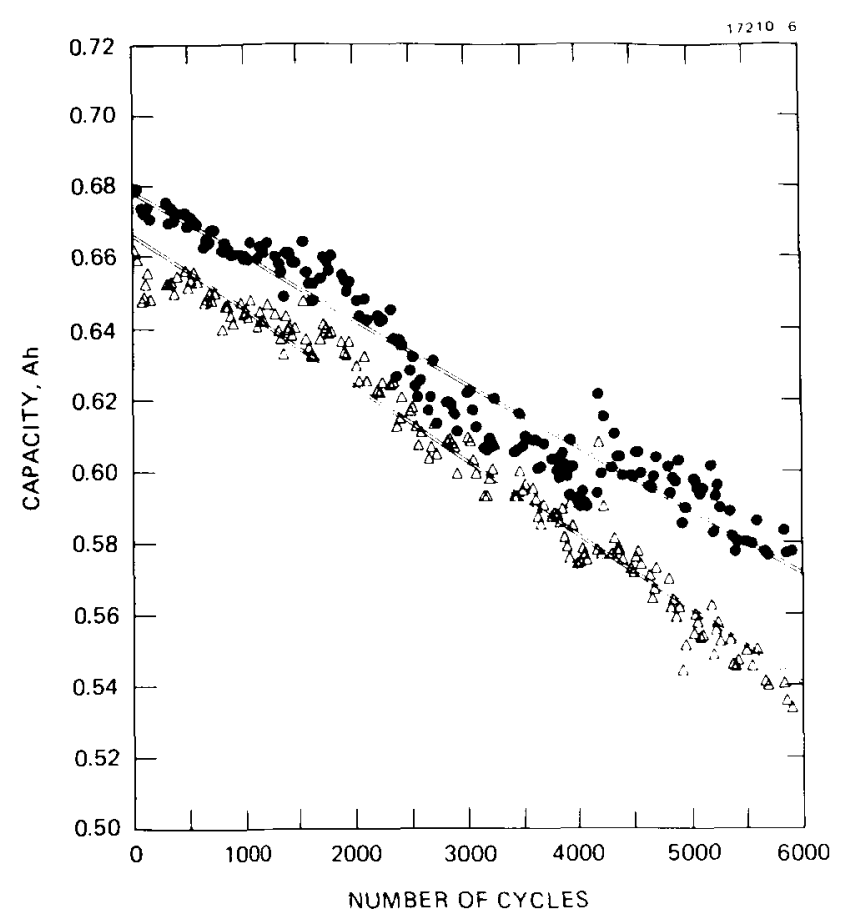

Fig. 6 Nickel electrode capacity versus number of cycles at $100 \%$ DOD in flooded cell with $26 \% \mathrm{KOH}$ electrolyte for duplicate cells.

by cell design or the cell's intrinsic cycle life, and that, therefore, the relationship between cycle life and DOD is rigidly fixed. Improved cell design and intrinsic cycle life are related only to the value of $R$. For example, as shown in Fig. 7, variations in intrinsic cycle life for different types of cells result in vertical displacements of curves plotting cycle life as a function of DOD, without changing the curves' slopes or shapes.

The figure also suggests that a meaningful accelerated cycle life test using a higher value of DOD than that of an actual mission can be carried out at considerable savings in time and cost.

The relative positions of the curves in Fig. 7 clearly show the cells' relative cycle $\mathrm{life}$ merits. Improved $\mathrm{Ni} / \mathrm{Cd}$ cells using zirconia separators (curve C) have much longer cycle lives than do the cells containing nylon separators (curve B), now in use. A recent study ${ }^{4}$ showed that the cycle life of a $\mathrm{Ni} / \mathrm{H}_{2}$ cell with an improved electrolyte $(26 \% \mathrm{KOH})$ is several times longer than that of a similar cell containing the current standard electrolyte of $31 \% \mathrm{KOH}$. A predicted minimum cycle life of the cell with the improved electrolyte is shown by curve D, whereas a predicted cycle life for a current standard $\mathrm{Ni} / \mathrm{H}_{2}$ cell should be close to curve $\mathrm{C}$.

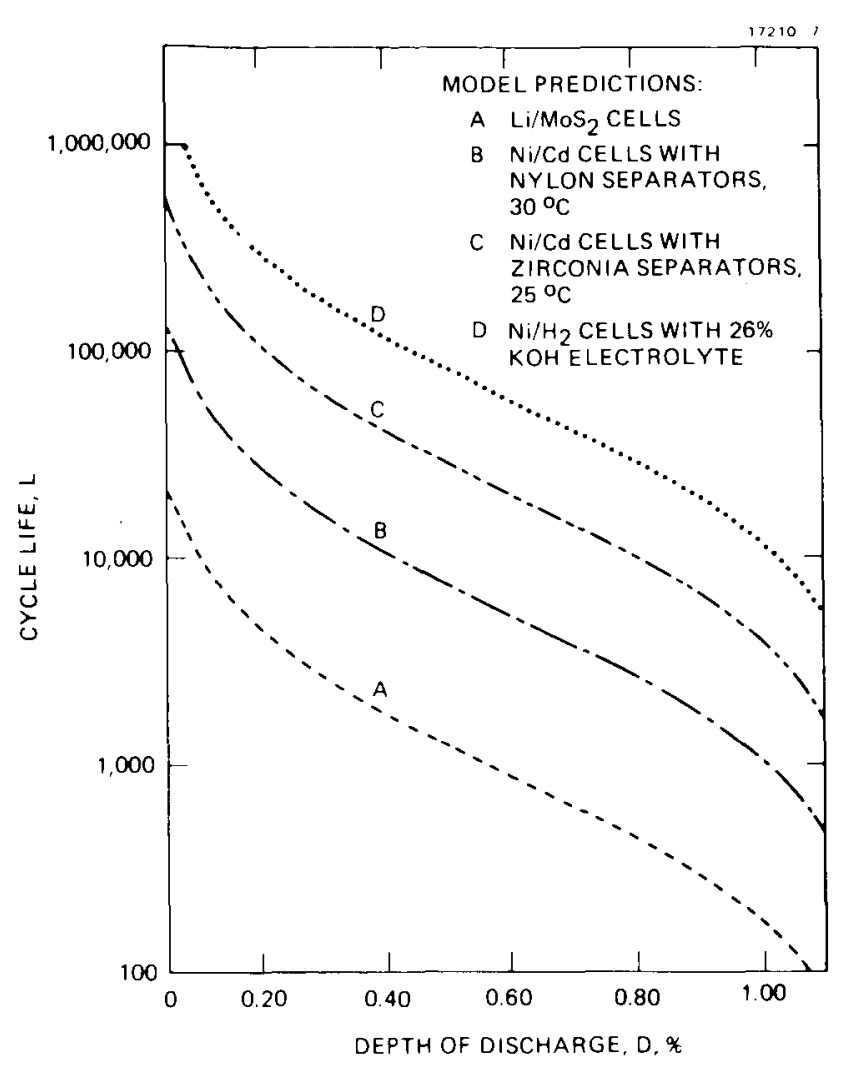

Fig. 7 Cycle life versus DOD for various cell types.

The mechanisms that cause a gradual loss of capacity are not yet well understood. However, it is clear that even the most advanced cells suffer from subtle morphological changes and chemical degradation over time. As those processes are identified, real improvements in electrochemical devices should follow. Modeling of cycle life as a function of depth of discharge, based on the results of accel erated testing, will be a valuable tool for prompt evaluation of those improvements.

\section{Conclusions}

The proposed model appears to be more useful than those presented earlier, $1-4$ though it too has flaws. The results discussed here support the following conclusions:

- When a cell fails because of a gradual loss of capacity (wearout), the relationship between cycle life and depth of discharge is rigidly fixed. Thus, meaningful accelerated cycle life testing can be performed at considerable savings in time and cost. 
- Though the slope of a typical cyclelife-versus-DDD plot suggests that cycle life should roughly double with each $20 \%$ reduction in the DOD of cycling, cycle life can also be improved without reducing DOD by the use of advanced components and design. This paper includes the results of tests on experimental cells incorporating improved (chemically resistant) separator materials, rather than the nylon separators now standard in aerospace $\mathrm{Ni} / \mathrm{Cd}$ cells. The improved separators do not affect cycle 1 ife in a way that changes the slope of the plot, but do cause a vertical displacement of the curve (as shown in Fig. 7) by an amount proportional to the improvement in the rate of capacity loss.

Some of the $\mathrm{Ni} / \mathrm{H}_{2}$ cell cycling test results suggest that a better (lower) value of $R$ may derive from the use of alternative electrolyte compositions to achieve more favorable energy densities and cycle lives for future $\mathrm{Ni} / \mathrm{H}_{2}$ cells.

\section{Acknowledgments}

We would like to acknowledge the support of the National Aeronautics and Space Administration, Lewis Research Center, for the cycle life testing of nickel electrodes (Contract NAS 3-22238; Project Manager: John Smithrick).

\section{References}

1. H.N. Seiger, "Effects of depth of discharge on cycle life of near term batteries," Proc. 16th Intersociety Energy Conversion Engineering Confer ence, Atlanta, Ga., 1981, p. 102 .

2. D. Schwartz, "Accelerated test modeling, " 1978 Goddard Space Flight Center Battery Workshop, National Aeronautics and Space Administration (Greenbelt, Md.), NASA Conference Publication 2088, 1978, p. 119.

3. P. McDermott, "Nonlinear prediction modeling for accelerated testing," 1978 Goddard Space Flight Center Battery Workshop, National Aeronautics and Space Administration (Greenbelt, Md.), NASA Conference Publication 2088, 1978, p. 135.

4. J. Lander, "NWSC nickel-cadmium spacecraft cell accelerated life test program data analysis," 1979 Goddard Space Flight Center Battery Workshop, National Aeronautics and Space Administration (Greenbelt, Md.), NASA Conference Publication 2117, 1979 , p. 391 .
5. L.H. Thaller, Expected Cycle Life vs. Depth of Discharge Relationships of Well Behaved Single Cells and Cell Strings, National Aeronautics and Space Administration, Lewis Research Center (Cleveland, Ohio), NASA Technical Memorandum 82957, 1982

6. L.H. Thaller, "Synthetic battery cycling," Proc. 16th Intersociety Energy Conversion Engineering Conference, Atlanta, Ga., 1981, p. 667 .

7. "Accelirated test program," prepared for Jet Propulsion Laboratory by the Naval Weapons Support Center (Crane, Ind.), Interim Report, 3 May 1979.

8. Accelerated Test Plan for Nickel Cadmium Spacecraft Batteries, Goddard Space Flight Center (Greenbelt, Md.), Publication X-761-73-183, October 1973.

9. H.S. Lim et al., "New separators for nickel-cadmium cells," Proc. 16th Intersociety Energy Conversion Engineering Conference, Atlanta, Ga, 1981, p. 182 .

10. H.S. Lim et al., "Long life $\mathrm{Ni} / \mathrm{Cd}$ cells with zirconia separators: accelerated cycle tests," Proc. 17th Intersociety Energy Conversion Engineering Conference, Los Angeles, Calif., 1982, p. 716.

11. H.S. Lim et al., "Studies on the stability of nylon separator material," 27 th Annual Proc. Power Sources Conference, Atlantic City, N.J., June 1976, p. 83.

12. J.A. Stiles, "Performance and safety characteristics of lithium-molybdenum disulfide cells," 1983 Goddard Space Flight Center Battery Workshop, National Aeronautics and Space Administration (Greenbelt, Md.), NASA Conference Publication 2331, 1983, p. 65 .

13. H.S. Lim and S.A. Verzwyvelt, "Long Iife nickel electrodes for a nickelhydrogen cell: III. Results of an accelerated test, and failure analysis," Proc. 19th Intersociety Energy Conversion Engineering Conference, San Francisco, Cal if., 1984, p. 312.

14. H.S. Lim and S.A. Verzwyvelt, "Cycle Iife of nickel-hydrogen cells: II. Accelerated cycle life test," Proc. 21 st Intersociety Energy Conversion Engineering Conference, San Diego, Calif., 1986, p. 1601.

\section{ORIGINAL PAGE IS Or. POOR QUALTYY}




\begin{tabular}{|c|c|c|}
\hline $\begin{array}{ll}\text { 1. Report No. } & \text { NASA TM-89915 } \\
& \text { AIAA-87-9080 }\end{array}$ & 2. Government Accession No. & 3. Recipient's Catalog No. \\
\hline \multicolumn{2}{|l|}{ 4. Title and Bubitite } & 5. Report Date \\
\hline \multicolumn{2}{|c|}{$\begin{array}{l}\text { A Prediction Model of the Depth-of-0ischarge } \\
\text { Effect on the Cycle Life of a Storage Cell }\end{array}$} & $\begin{array}{l}\text { 6. Performing Organization Code } \\
506-41-21\end{array}$ \\
\hline \multicolumn{2}{|l|}{ 7. Author(s) } & 8. Performing Organization Report No. \\
\hline \multirow{2}{*}{\multicolumn{2}{|c|}{ Lawrence H. Thaller and Hong S. Lim }} & $E-3608$ \\
\hline & & 10. Work Unit No. \\
\hline \multirow{2}{*}{\multicolumn{2}{|c|}{$\begin{array}{l}\text { 9. Performing Organization Name and Address } \\
\text { National Aeronautics and Space Administration } \\
\text { Lewis Research Center } \\
\text { Cleveland, Onto } 44135\end{array}$}} & \\
\hline & & \begin{tabular}{|l|} 
13. Type of Report and Period Covered \\
\end{tabular} \\
\hline \multicolumn{2}{|l|}{ 12. Sponsoring Agency Name and Address } & Technical Memorandum \\
\hline \multicolumn{2}{|c|}{$\begin{array}{l}\text { National Aeronautics and Space Administration } \\
\text { Washington, D.C. } 20546\end{array}$} & 14. Sponsoring Agency Code \\
\hline \multicolumn{3}{|l|}{ 15. Supplementary Notes } \\
\hline \multicolumn{3}{|c|}{$\begin{array}{l}\text { Prepared for the } 22 \text { nd Intersociety Energy Conversion Engineering Conference, } \\
\text { cosponsored by the AIAA, ANS, ASME, SAE, IEEE, ACS, and AIChE, Philadelphia, } \\
\text { Pennsylvania, August 10-14, 1987. Lawrence H. Thaller, NASA Lewis Research } \\
\text { Center; Hong S. Lim, Hughes Research Laboratories, Malibu, Caltfornia. }\end{array}$} \\
\hline \multicolumn{3}{|l|}{ 16. Abstract } \\
\hline \multicolumn{3}{|c|}{$\begin{array}{l}\text { Cycle } 1 \text { ife requirements are very high for batteries used in aerospace applica- } \\
\text { tions in low earth orbit. The data base required to establish confidence in a } \\
\text { particular cell design is thus both extensive and expensive. Reliable acceler- } \\
\text { ated cycle life testing and performance decay modeling represent attractive } \\
\text { alternatives to real-time tests of cycle life. In } 11 \text { hht of certain long-term } \\
\text { cycle life test results, this paper examines a very simple performance decay } \\
\text { model developed earlier. Application of that model to avaliable data demon- } \\
\text { strates a rigid relationship between a battery's expected cycle } 1 \text { ife and the } \\
\text { depth of discharge of cycling. Further, modeling analysis of the data suggests } \\
\text { that a significantly improved cycle life can be obtained with advanced compo- } \\
\text { nents, materlals, and designs; and that cycle life can be reliably predicted } \\
\text { from the results of accelerated testing. }\end{array}$} \\
\hline \multirow{2}{*}{$\begin{array}{l}\text { 17. Key Words (Suggested by Author(s)) } \\
\text { Nickel-cadmium } \\
\text { Cycle life model } \\
\text { Performance degradation } \\
\text { Life projection }\end{array}$} & & \multirow{2}{*}{$\begin{array}{l}\text { 18. Distribution Statement } \\
\text { Unclassified - unlimited } \\
\text { STAR Category } 44\end{array}$} \\
\hline & $\begin{array}{l}\text { Unc } \\
\text { STAF }\end{array}$ & \\
\hline $\begin{array}{l}\text { 19. Security Classif. (of thls report) } \\
\text { Unc lassif fed }\end{array}$ & $\begin{array}{l}\text { 20. Security Classif. (of this page) } \\
\text { Unc lass if led }\end{array}$ & \begin{tabular}{|c|c|} 
21. No. of pages & 22. Price* \\
8 & $\mathrm{AO2}$
\end{tabular} \\
\hline
\end{tabular}

"For sale by the National Technical Information Service, Springfield, Virginia 22161 